\title{
Profile of Patients Receiving Stroke Rehabilitation in A Tertiary Care Hospital
}

\author{
Prasanta Kumar Chakraborty ${ }^{1 *}$ \\ Md. Jahidul Islam² \\ Md. Shahadat Hossain ${ }^{3}$ \\ Sunam Kumar Barua ${ }^{2}$ \\ Sohely Rahman ${ }^{2}$
}

${ }^{1}$ Department of Physical Medicine \& Rehabilitation National Institute of Cancer Research and Hospital Dhaka, Bangladesh.

${ }^{2}$ Department of Physical Medicine \& Rehabilitation Dhaka Medical College

Dhaka, Bangladesh.

${ }^{3}$ Department of Physical Medicine and Rehabilitation Shaheed Suhrawardy Medical College Dhaka, Bangladesh.
${ }^{*}$ Correspondence to:

\section{Prasanta Kumar Chakraborty}

Assistant Professor

Department of Physical Medicine and Rehabilitation National Institute of Cancer Research and Hospital Dhaka, Bangladesh.

Mobile : +8801718 660967

E-mail: pkcborty@gmail.com

www.banglajol.info/index.php/CMOSHMCJ

\begin{abstract}
Background: Stroke rehabilitation is a program designed to help the stroke patients to overcome the disability. Few studies have evaluated the profile of stroke patients. To provide information about demographic data $\&$ disease pattern among the patients receiving stroke rehabilitation. Methods: A retrospective study was carried out in the Department of Physical Medicine and Rehabilitation (PMR), National Institute of Neuroscience and Hospital (NINSH) Dhaka, Bangladesh for the period of two year from $1^{\text {st }}$ July 2013 to $30^{\text {th }}$ June, 2015. Results: Total five thousand nine hundred thirty nine $(\mathrm{n}=5939)$ patients were studied, of which $62.33 \%$ were male and $37.67 \%$ were female. Maximum patients $(27.93 \%)$ belong to $51-60$ years of age. Major patients $(52.67 \%)$ came from Dhaka city and most of the studied patients were housewife $(25.43 \%)$. Largest disease group was ischaemic stroke $(81.7 \%)$. Regarding service pattern, $69.59 \%$ patients received outdoor and $30.41 \%$ indoor services. Among clinical profile of stroke, $90.5 \%$ were first time onset, almost $99 \%$ suffered limb weakness, $24.03 \%$ speech problem and $32.6 \%$ face involvement. Maximum patients $(58.8 \%)$ had history of multiple risk factors. Conclusion: Rehabilitation procedures in stroke patients can enable greater return of neurological functions and prevents complication, thereby improves long term outcome and quality of life.
\end{abstract}

Key words: Stroke; Rehabilitation; Profile of patients; PMR, NINSH.

\section{INTRODUCTION}

Stroke is one of the leading causes of death and disability worldwide and more so in underdeveloped countries like Bangladesh, where health support system including rehabilitation is not expectedly available ${ }^{1}$. Stroke is a disease of the brain where there is sudden onset of mostly focal lesion due to occlusion or rupture of a cerebral blood vessel and its symptomatology should last for more than twenty four hours. The incidence of stroke is increasing in this country in comparison to developed country. Although stroke is a disease of the elderly but in our country it is more common in 5th and 6th decade of life ${ }^{2}$. There are several important modifiable risk factors (hypertension, diabetes mellitus, tobacco smoking and obesity) which contribute to its pathophysiology ${ }^{3}$. Stroke is always a medical emergency. So it should be addressed as early as possible. About $50 \%$ of the stroke patient may need treatment in the hospital. The ultimate objective is to rehabilitate the patient. The patient should be referred to the physical medicine expert as a part of rehab as early as possible ${ }^{2}$.

National Institute of Neuro-sciences (NINS) in Bangladesh was established with the vision of making this institute as the center of excellence not only in this country but also for others. It is a matter of pride that the institute has started functioning from September 2012. There are more than 15 departments ${ }^{4}$. Physical Medicine and Rehabilitation is one of them. Almost all the patients came to this department were referred from different departments of NINSH. From July 2013 to June 2015, total 5939 patients received stroke rehabilitation services. 


\section{Objectives}

To observe the pattern of stoke patients attending at the department of PMR in a tertiary level hospital. To identify demographic characteristics of stroke patients and to discuss the findings of this study with other available studies.

\section{MATERIALS AND METHODS}

We undertook a retrospective review of the records at PMR Department of NINSH, Dhaka over a period of two year from $1^{\text {st }}$ July 2013 to $30^{\text {th }}$ June 2015 and determined the stroke diagnosis of attending patients. Information was extracted from the patients ' records by means of a questionnaire assessing the participants`demographics and diagnoses. The subjects were enrolled on an individual basis, despite the varying number of visits by a given patient during the period of study.

Data analysis: After collection of the data in a standardized proforma, all the data were analyzed and presented in simple statistical percentage. MS Excel was used for presentation of outcome picture.

Variables:

- Primary variables: o Stroke profile

- Secondary variables: o Age o Sex

o Catchment area

o Occupation

\section{RESULTS}

Table 1 : Socio-demographic characteristics of stroke patients $(\mathrm{n}=5939)$

\begin{tabular}{|c|c|c|c|}
\hline & Characteristics & $\begin{array}{l}\text { Number of } \\
\text { patients }\end{array}$ & Percentage (\%) \\
\hline \multirow[t]{2}{*}{ Sex } & Male & 3702 & 62.33 \\
\hline & Female & 2237 & 37.67 \\
\hline \multirow[t]{5}{*}{ Age (In years) } & Below 40 years & 568 & 9.56 \\
\hline & $41-50$ years & 1047 & 17.63 \\
\hline & $51-60$ years & 1659 & 27.93 \\
\hline & years & 1562 & 26.30 \\
\hline & Above 70 years & 1103 & 18.57 \\
\hline \multirow[t]{2}{*}{ Catchment area (Residency) } & Dhaka city & 3128 & 52.67 \\
\hline & Outside Dhaka city & 2811 & 47.33 \\
\hline \multirow[t]{9}{*}{ Occupation of patient } & Service holder & 997 & 16.79 \\
\hline & Retired Service holder & 868 & 14.62 \\
\hline & Housewife & 1510 & 25.43 \\
\hline & Laborer & 528 & 8.89 \\
\hline & Farmer & 620 & 10.44 \\
\hline & Businessman & 647 & 10.89 \\
\hline & Student & 42 & 0.71 \\
\hline & Unemployed & 381 & 6.42 \\
\hline & Others & 346 & 5.83 \\
\hline
\end{tabular}

Table 2 : Service provided

\begin{tabular}{lllc}
$\begin{array}{l}\text { Serial } \\
\text { Number }\end{array}$ & Disease & $\begin{array}{l}\text { Number of } \\
\text { patients }\end{array}$ & Percentage (\%) \\
\hline 1 & Outdoor services & 4133 & 69.59 \\
2 & Indoor services & 1806 & 30.41 \\
& Total & 5939 & $100 \%$ \\
\hline
\end{tabular}

Table 3 : Profile of stroke patients $(n=5939)$

\begin{tabular}{|c|c|c|c|}
\hline & Characteristics & $\begin{array}{l}\text { Number of } \\
\text { patients }\end{array}$ & Percentage (\%) \\
\hline \multirow[t]{2}{*}{ Stoke type } & Ischaemic & 4852 & 81.70 \\
\hline & Hemorrhagic & 1087 & 18.30 \\
\hline \multirow[t]{2}{*}{ Stroke onset } & First time & 5375 & 90.5 \\
\hline & Recurrent & 564 & 9.5 \\
\hline \multirow{8}{*}{$\begin{array}{l}\text { Parts of body } \\
\text { affected }\end{array}$} & Hemiplegia/Hemiparesis & & \\
\hline & Right side & 3083 & 51.91 \\
\hline & Left side & 2693 & 45.34 \\
\hline & Tetraplegia/ Tetraparesis & 47 & 0.79 \\
\hline & Speech problem & 1427 & 24.03 \\
\hline & Face involvement & 1936 & 32.6 \\
\hline & Others (paraplegia/paraparesis/ & & \\
\hline & monoplegia/monoparesis etc.) & 116 & 1.95 \\
\hline \multirow{5}{*}{$\begin{array}{l}\text { Factors associated } \\
\text { with stroke }\end{array}$} & & & \\
\hline & $\begin{array}{l}\text { Single risk factor } \\
\text { (Diabetes mellitus/ } \\
\text { Hypertension/Heart diseases }\end{array}$ & & \\
\hline & / Hyperlipidaemia/Others). & 989 & 16.65 \\
\hline & Multiple risk factor & 3492 & 58.80 \\
\hline & No risk factor & 1458 & 24.55 \\
\hline
\end{tabular}

Problems demanded for Rehabilitation of stoke patients were Limb weakness, Facial weakness, Speech problem, Swallowing problem, gait abnormality and activities of daily livings.

\section{DISCUSSION}

A Uniform Data System (UDS) for Medical Rehabilitation is maintained in USA and published annually. No such system exists in Bangladesh ${ }^{5}$. In this study it has been tried to find out the age, sex, occupation, residency and disease pattern of the stroke patients attending in the Department of PMR.

In this study, $62.3 \%$ of patients were male and $37.67 \%$ were female. A study conducted by Eapen RP et al showed cerebrovascular stroke are more common in males $(67 \%)$ than females $(33 \%)^{6}$. Vaidya CV et al found $59.7 \%$ males and $40.3 \%$ females. Kapoor D et al stated $67.9 \%$ were males and $32 \%$ were females ${ }^{7,8}$. Hossain AM et al showed $74 \%$ males and females $26 \%$ in their study 9 .

In our study, $9.56 \%$ of patients were under 40 years of age, $17.63 \%$ were $41-50$ years, $27.93 \%$ were $51-60$ years, $26.3 \%$ were $61-70$ years and $18.57 \%$ were above 70 years of age. Kundu NC et al showed $16 \%$ under 40 years of age, $19 \%$ were $40-49$ years, $11 \%$ were $50-59$ years, $30 \%$ were $60-69$ years and $24 \%$ were above 70 years of age ${ }^{10}$. Eapen RP et al showed incidence of stroke is maximum in 51-60 years which comprises $28 \%$ 
of total patients ${ }^{6}$. Vaidya $\mathrm{CV}$ et al found $15.6 \%$ under 40 years of age, $17.2 \%$ were $41-50$ years, $22.3 \%$ were $51-60$ years, $32.8 \%$ were $61-70$ years and $19.3 \%$ were above 70 years of age $^{7}$. Hossain AM et al studied that $6 \%$ under 40 years of age, $14 \%$ were $41-50$ years, $39 \%$ were $51-60$ years, $30 \%$ were $61-70$ years and $11 \%$ were above 70 years of age ${ }^{9}$.

This study stated that occupations of patients were housewife $(25.43 \%)$ labourer (8.89\%) serviceman (16.79\%) retired serviceman $(14.62 \%)$ farmer $(10.44 \%)$ businessman $(10.89 \%)$ student $(0.71 \%)$. Hossain AM et al enlisted housewife $(16 \%)$ retired $(21 \%)$ serviceman $(28 \%)$ agriculture $(9 \%)$ businessman $(17 \%)$ others $(9 \%)^{9}$.

Most of the studied patients were coming from Dhaka city $(52.67 \%)$ and from outside Dhaka city it was $47.33 \%$. Probably this situation may be due to frequent use of bus for movement and journey. Masud MH et al showed that urban patients were $75.36 \%$ and rural patients were $24.63 \%{ }^{11}$. On the other hand, for the metropolitan area patients feel easy to reach in the hospital. Shakoor MA et al showed in their study that most of the patients $(65.7 \%)$ used bus for movement and journey ${ }^{12}$. Hossain AM et al showed that urban people were 54\% and rural were $46 \% 9$. But, Kapoor D et al stated, of the total, only $8.5 \%$ patients belonged to urban area and $91.4 \%$ belonged to rural $\operatorname{area}^{8}$.

In the present study it was found that $69.59 \%$ patient received outdoor service and $30.41 \%$ indoor service. Uddin MMJ et al stated most of the patients $98.32 \%$ were referred from Outpatient Department (OPD) and only $1.68 \%$ patients were refereed from indoor service ${ }^{13}$.

Among the disease pattern, first time onset of stroke was $90.5 \%$ and recurrent case was $9.5 \%$. Vaidya $\mathrm{CV}$ et al found that previous history of cerebro-vascular accident $15 \%{ }^{7}$. Hossain AM et al showed that among the stroke patients $9 \%$ had previous history of stroke 9 .

$81.7 \%$ ischaemic and $18.3 \%$ hemorrhagic stroke were found in our study. Eapen RP et al showed $68 \%$ was ischaemic and $32 \%$ hemorrhagic stroke ${ }^{6}$. Vaidya $\mathrm{CV}$ et al found that $74.8 \%$ suffered ischemic stroke and $22.7 \%$ suffered hemorrhagic stroke followed by $2.5 \%$ were due to some primary brain malignancy or secondaries in brain ${ }^{7}$. Hossain AM et al showed that $61 \%$ was ischaemic and $18.3 \%$ hemorrhagic stroke ${ }^{9}$. Kundu NC et al found $37.5 \%$ patients developed hemorrhagic stroke and $62.5 \%$ patients suffered an ischemic attack ${ }^{10}$.

Most common clinical presentation was limb weakness either hemiplegia/hemiparesis (97.25\%) of which 51.91\% right side and $45.34 \%$ left side affected. Both side affected (Tetraplegia/ tetraparesis) was $0.79 \%$, speech problem $24.03 \%$, face involvement $32.6 \%$ and others (paraplegia/ paraparesis/ monoplegia/ monoparesis etc) were $1.95 \%$. Eapen RP et al showed hemiplegia with facial weakness $83 \%$, speech abnormality $48 \%{ }^{6}$. Vaidya CV et al found hemiplegia $48 \%$, speech abnormality $25.1 \%$, altered sensorium $13.1 \%{ }^{7}$. Kapoor $\mathrm{D}$ et al stated weakness of limb present in $73 \%$, mouth deviation $47.5 \%$, speech abnormality $53 \%$, altered sensorium $47.3 \%$, monoparesis $0.02 \%{ }^{8}$.
In present study, maximum patients $(58.8 \%)$ had history of multiple risk factors, $16.65 \%$ had single risk factor and no risk factor was found in case of $24.55 \%$. Kundu NC et al showed on the basis of risk factors $55 \%$ patients had multiple risk factors, $16 \%$ had single while no risk factor was found in $29 \%$ patients ${ }^{10}$. Chowdhury $\mathrm{RN}$ et al found that hypertension, diabetes, ischemic heart disease, dyslipidaemia and respiratory problem were significantly associated co-morbid conditions in stroke patients ${ }^{14}$.

From the above discussion, it is clearly demonstrated that the findings of the study performed in PMR department of NINSH is consistent with the findings of available studies.

\section{CONCLUSION}

Stroke is one of the foremost causes of morbidity, mortality and a socioeconomic challenge. This is particularly true for developing countries like Bangladesh, where health support system including the rehabilitation system is not within the reach of ordinary people. This study may have not reflected the exact situation but gives an utmost picture of the disease.

\section{LIMITATIONS}

This study is done in one tertiary level hospital of Bangladesh in a small population and it may not reflect the total scenario of patients getting treatment from Physical Medicine \& Rehabilitation Department.

\section{RECOMENDATIONS}

i) A large scale multi-centered study should be performed in the country

ii) A uniform data system should be constructed for stroke rehabilitation in Bangladesh.

\section{ACKNOWLEDGEMENT}

We express deepest regards and a profound debt of heart full gratitude to Dr. Md. Khurshid Mahmood, Associate Professor and Head, Department of PMR, Professor M Badrul Alam, Joint Director and Professor Quazi Deen Mohammmad, Director of NINSH, Dhaka. We would like to thanks our fellow colleagues, medical technologist and finally our family members for their kind cooperation and assistance in carrying out the study.

\section{DISCLOSURE}

All the authors declared no competing interest. 
REFERENCES

1. Nessa J, Khaleque MA, Begum S, Ahmed AH, Islam MS, Afsan M. Rehabilitation of Stroke Patients - Effects of Early Intervention of Physical Therapy on Functional Outcome. Bangladesh J. Anat. 2009; 7(1): 62-67.

2. Mohammad QD. Management of stroke - Bangladesh perspective. Bangladesh Med J. 2013; 42 (1).

3. Seshadri S, Beiser A, Kelly-Hayes M, Kase CS, Au R, Kannel WB et al. The lifetime risk of stroke: estimates from the Framingham study. Stroke. 2006; 37: 345-350.

4. Mohammad QD. Establishment of National Institute of Neuroscience and Hospital, Bangladesh perspective [Editorial]. J Natl Inst Neurosci Bangladesh.2015; 1(1):1.

5. Hossain MS, Chakraborty PK, Rahman S, Islam MJ, Amin MR, Saha RK et al. Diseases pattern in the department of Physical Medicine \& Rehabilitation in a tertiary level hospital. Bangladesh Med J. 2014; 43(3):130-133.

6. Eapen RP, Parikh JH, Patel NT. A study of clinical profile and risk factors of cerebrovascular stroke. GMJ, 2009; 64(2):47-54.

7. Vaidya CV, Majmudar DK .A retrospective study of clinical profile of stroke patients from GMERS Medical College and Hospital, Gandhinagar, Gujarat. Int J Clin Trials. 2014; 1(2):62-66.

8. Kapoor D, Gupta P, Sundar S, Sharma R, Dhiman A, Agarwal V. Study of the profile of stroke in a tertiary-care hospital in the subHimalayan region in north India. International Journal of Medical Science and Public Health. 2015; 4(1):124-128.

9. Hossain AM, Ahmed NU, Rahman M, Islam MR, Sadhya G, Fatema K. Analysis of Sociodemographic and Clinical Factors Associated with Hospitalized Stroke Patients of Bangladesh. Faridpur Med. Coll. J. 2011; 6(1):19-23.

10. Kundu NC, Ahmed Q, Sen M. Study of stroke and its risk factors among admitted patients in a tertiary level hospital. Bangladesh Journal of Neuroscience. 2010; 26(2): 86-91.

11. Masud MH, Rahman MZ, Parveen S, Rana MA, Chowdhury MS, Rahman MA et al. Demographic and Clinical Profile of Patients with Irritable Bowel Syndrome Attending in Gastroenterology Out Patient Department of BSMMU. Comilla BMA Med J. 2012; 27(2):15-18.

12. Shakoor MA, Islam MA, Ullah MA, Ahmed MM, Hasan SA. Clinical profile of the patients with chronic low back pain-A study of 102 cases. JCMCTA. 2007; 18(2): 16-20.

13. Uddin MMJ, Chowdhury MSJH, Islam MJ, Chowdhury TI, Baqui M, Sarker PK et al. Referral Pattern of Patients to Psychiatry Department in National Institute of Neurosciences and Hospital, Dhaka. J Natl Inst Neurosci Bangladesh. 2015; 1(1): 8-11.

14. Chowdhury RN, Hasibul Hasan ATM, Rahman YU, Khan SI, Hussain AR, Ahsan S. Pattern of neurological disease seen among patients admitted in tertiary care hospital. BMC Research Notes. 2014; 7:202. 